\title{
The Effect of Wartime Legacies on
}

\section{Electoral Mobilization after Civil War*}

\author{
Felix Haass
}

\author{
Martin Ottmann
}

\begin{abstract}
Elections are cornerstones for societies transitioning from civil war to democracy. The success or failure of these elections is shaped by the strategies former rebels employ to mobilize voters. Of those strategies, clientelism is particularly important as it represents improved voter-elite relations over dysfunctional wartime politics, but, if pervasive, also risks undermining long-term democratic consolidation. We argue that the organizational legacies of rebellion shape the way how rebels engage in electoral clientelism. We expect that former rebels target pre-electoral benefits to areas of wartime support; rely on wartime military networks to deliver those benefits; and exploit discretionary control over peace dividends when allocating electoral benefits. We combine original geospatial data on the timing and location of over 2,000 tsunami aid projects with village-level surveys in post-civil war Aceh, Indonesia, to test these hypotheses. Results from difference-in-differences models and detailed tests of causal mechanisms are consistent with our theoretical expectations.
\end{abstract}

Keywords: Clientelism; Post-Conflict Democracy; Electoral Mobilization; Reconstruction Aid

*We acknowledge support from the German Research Foundation (OT 494/1-1, ME 1701/7-1). Felix Haass acknowledges funding from the European Research Council (ERC) under the European Unions Horizon 2020 research and innovation program (grant agreement no. 863486). Supplemental materials are available in an Online Appendix. Replication files are available in the JOP Dataverse (https://dataverse.harvard.edu/dataverse/jop). The empirical analysis has been successfully replicated by the JOP replication analyst. 


\section{Introduction}

In societies emerging from civil war, elections constitute a cornerstone of war-to-democracy transitions (Jarstad and Sisk 2008; Flores and Nooruddin 2012). A key ingredient for the success or failure of post-conflict elections is the behavior of former rebel groups competing in them. During war, rebels derive political authority from effectively and often violently controlling territory and civilians (Kalyvas 2006; Stewart 2018; Weinstein 2007). Elections after war, however, introduce political competition over who holds executive office, thus jeopardizing these wartime sources of rebel power (Arjona, Kasfir, and Mampilly 2015; Jarstad and Sisk 2008). Consequently, rebels need to develop different strategies to maintain political power. Which strategies rebels ultimately employ to meet this challenge, such as electoral violence, ethnic appeals, and/or clientelism, is critical for the trajectory of post-conflict peace and democracy (Daly 2019; Daxecker, Amicarelli, and Jung 2019; Hadzic, Carlson, and Tavits 2020; Matanock 2017).

Clientelism as a mobilization strategy plays a central role for democratic development after war because of its double-edged nature. On the one hand, pervasive clientelism risks undermining citizens' ability to hold politicians accountable and erodes their trust in institutions (Hicken 2011, 302). On the other hand, clientelism represents an improved way for citizens to at least secure some benefits from the state (Fukuyama 2014; Hicken 2011)_especially when compared to even more dysfunctional politics during a war. But despite these implications of clientelistic mobilization for post-conflict democracy, our understanding of where, why, and how former insurgents engage in this electoral strategy is limited.

To address this gap, we develop a general theory of rebels' clientelistic electoral mobilization after war and investigate how this strategy is shaped by wartime legacies. Once conflict ends, former rebels running for office require civilian support to win political power not through violence but through winning elections. We argue that wartime legacies make clientelism—targeted transfers of selective public goods contingent on recipients' political support-an effective strategy for former rebels to generate electoral support after war (Stokes et al. 2013). We identify three legacies that we expect to shape clientelistic elec- 
toral mobilization after war. First, locations where rebels received civilian support during war are likely to receive pre-electoral benefits. Second, the remnants of rebels' military organization can form the basis for party structures and broker networks to deliver those benefits. Third, the degree to which former rebels have discretionary control over economic peace dividends, should determine how and what types of goods they deliver.

We examine the post-conflict setting in the Indonesian province of Aceh to test this theory. The Acehnese setting has three advantages that make it uniquely suited for this purpose. First, after the tsunami in 2004 and the ensuing peace agreement in 2005, the Free Aceh Movement (Gerakan Aceh Merdeka, GAM) and the Government of Indonesia (GoI) established a government agency tasked with coordinating the reconstruction effort, the Agency for the Rehabiliation and Reconstruction of Aceh and Nias (Badan Rehabilitasi dan Rekonstruksi, BRR). Our research design exploits the fact that the 2005 peace agreement stipulated that GAM receive a number of influential positions within the BRR agency. These positions allowed the rebels to influence the allocation of tsunami aid to electorally beneficial locations-their wartime constituencies. Second, given that the BRR agency was a government ministry rebels did not have unfettered access to reconstruction funds. Instead, rebels access to BRR funds was under stronger scrutiny than their access to other, specifically post-conflict funds (Tajima 2016). This limited access makes the BRR a hard case to test a theory of wartime legacies and clientelistic electoral mobilization: If former insurgents can find ways to use even limited access to funding with strong oversight for electoral purposes, it is likely that we would observe similar behavior in cases with more direct access. Finally, the BRR agency set up a database to coordinate aid projects in the province. We were able to retrieve a full copy of this database, allowing us to create an original, highly geographically disaggregated dataset on tsunami aid allocation in Aceh. We link this data to fine-grained information from the Indonesian National Violence Monitoring System (Sistem Nasional Pemantauan Kekerasan, SNPK) (Government of Indonesia 2018) to identify the location of plausible wartime civilian support for GAM.

We use a difference-in-differences design to overcome a key research design challenge: disentangling political determinants for aid allocation from tsunami-related drivers of aid 
reception. Consequently, we compare the number of new aid projects between sub-districts with and without wartime GAM support before and after the 2006 gubernatorial elections in Aceh, the first elections after the end of the war. In this way, we are able to control for time invariant differences across sub-districts, such as tsunami damage, while leveraging the timing of the elections as treatment.

Consistent with a theoretical model that predicts targeted benefit allocation for preelectoral mobilization, we show that GAM areas received approximately $10 \%$ more new aid projects than non-GAM areas before, but not after the 2006 election. To further probe the robustness of our results, we replicate the main findings using village-level survey data from the Aceh Reintegration and Livelihood Surveys (Barron et al. 2008; Tajima 2010). Additional results provide evidence for the underlying mechanisms. We show that rebels used wartime military networks to deliver benefits and that they used their discretionary control over some sectors of tsunami aid to circumvent donor monitoring.

Our theory of post-conflict electoral mobilization advances the literature on post-conflict democratization. While some scholars emphasize the potential of elections to balance out group interests in deeply divided societies (Flores and Nooruddin 2012; Matanock 2017), others emphasize the potential of political capture of institutions for the private political benefits of post-conflict actors (Lake 2017; Zürcher et al. 2013). Our findings speak to the latter group of studies. We demonstrate that wartime legacies in combination with former rebels' access to peace dividends can distort the post-conflict democratization process by facilitating clientelistic practices. Our findings also speak to the literature on the origins of clientelism in the developing world (Hicken 2011; Golden and Min 2013), and especially in Indonesia (Aspinall and Berenschot 2019). We identify the insurgent-civilian links and organizational legacies of civil wars as core driver of clientelistic practices. This finding adds a novel explanation to why clientelism is an attractive electoral strategy in conflict contexts.

\section{Electoral Mobilization After War}

Post-conflict elections have become a central milestone in war-to-peace transitions around the globe (Flores and Nooruddin 2012). To successfully contest elections, however, former 
rebels depend on popular support even after an armed conflict has come to an end (Kalyvas 2006). Empirical evidence from diverse cases such as post-civil war Italy, Ireland, El Salvador, Nicaragua, Nepal, or Mozambique suggests that former rebels often manage to translate wartime civilian support into votes, sometimes even winning elections (Costalli and Ruggeri 2019; Daly 2019; Manning and Smith 2019). How do they accomplish this?

In most instances, rebels' electoral success only weakly rests on clear political programs that match voters' partisan preferences. Civil wars destroy the trust of voters that public policies will be implemented once election winners gain office (De Juan and Pierskalla 2016). Moreover, post-conflict states often do not possess the organizational capacities necessary to implement such programs (Gates et al. 2012). Aware of this, former rebels often shy away from developing fully refined and ideological coherent policy positions that would appeal to a broader set of voters by clearly distinguishing them from their competitors (Sindre 2019; Sprenkels 2019).

Existing research has therefore investigated a range of possible strategies of voter mobilization. First, former rebels often rely on violence and intimidation to suppress the vote shares of their competitors (Birch, Daxecker, and Höglund 2020). Second, former rebels can appeal to ethnic or religious identities, building on the pivotal role these affiliations played prior and during a civil war (Hadzic, Carlson, and Tavits 2020). Third, former rebels can appeal to voters' demand for protection from renewed violence-which is typically offered by the victorious or the military superior party at the end of a conflict (Daly 2019).

However, these strategies of voter mobilization come with limitations. Electoral violence, for example, is a costly strategy as it tarnishes international reputation and may result in the loss of donor support or could lead to intervention by the host state (Birch, Daxecker, and Höglund 2020). Ethnic or religious identities, on the other hand, can be insufficient to motivate voters to cast their ballot in favor of a party due to the heterogeneity and fluidity of these identities (Kalyvas 2008). Former rebels' relying on a security message also face the problem that their potential audience is likely to be heterogeneous. In both instances, former rebels have to make the difficult choice where and how to target mobilization efforts within their prospective electoral base. 
Electoral clientelism is a complementary strategy that can address these strategies' limitations. In a clientelist strategy, party elites match voters' demands for such benefits by directly handing out payments or gifts to voters, contingent on voters' electoral support (Hicken 2011; Kitschelt and Wilkinson 2007; Nichter 2008; Stokes et al. 2013). ${ }^{1}$ Parties use brokers-local intermediaries between party officials and voters-to circumvent information problems on supporters' location and identity and to hand out benefits efficiently and effectively (Stokes et al. 2013). At the same time, clientelism is often less visible than electoral intimidation (Hicken 2011). These features make clientelism an effective strategy to complement violent electoral mobilization (Rauschenbach and Paula 2019) and to target supporters within a heterogeneous electoral base (Golden and Min 2013; Stokes et al. 2013).

There is some evidence that former rebels indeed engage in clientelist mobilization during post-conflict elections alongside the previously mentioned strategies. Several studies find that the risk of losing access to patronage networks shapes electoral strategies by "warlord democrats" in the Democratic Republic of the Congo, Guinea-Bissau, Mozambique, Sierra Leone, and South Sudan (see the contributions to Themnér 2017). Others argue that clientelism can be a rational response of former warring factions to external pressures for post-conflict democratization (Haass 2021; Zürcher et al. 2013).

Despite the importance of clientelism as a voter mobilization strategy and evidence for its use in post-conflict politics, we are missing systematic evidence on when, where, and how former rebels engage in electoral clientelism. Researching clientelism is empirically extremely demanding, even in non-conflict contexts. It typically requires fine-grained information on timing and location of material benefits as well as distribution of voter partisan identities (Kramon 2017, 22-24; Stokes et al. 2013). This problem is exacerbated in the information-scarce environment of post-conflict politics. An important side-effect of these empirical problems is that they also result in a lack of a concise theoretical understanding of

\footnotetext{
${ }^{1}$ In contrast to pork barrel strategies or programmatic appeals, goods that are distributed clientelistically do not follow public criteria of distribution. This lack of public criteria makes clientelist strategies illegal in many countries.
} 
the mechanisms of post-conflict clientelism. By combining a novel theory on how wartime legacies shape post-conflict clientelism with original data on post-conflict aid allocation, this article addresses both challenges.

\section{The Effect of Wartime Legacies on Clientelism}

To explain how former rebels engage in clientelism, we discuss three wartime legacies that facilitate such an electoral strategy. The civilian support that rebels established during the armed conflict; rebels' military organization; and the degree to which rebels have access to economic peace dividends that they can repurpose for electoral benefits.

\section{Rebel Constituencies After Civil War}

To date, there is no clear answer to the question whether it is more efficient for a party leader to target core supporters or swing voters with benefits (Stokes 2011). ${ }^{2}$ If anything, evidence from across the world suggests that the choice of targeting swing versus core voters is ultimately driven by the specific context in which the vote takes place (Golden and Min 2013; Stokes et al. 2013, 138ff.). In a post-conflict setting, we expect that wartime legacies make it rational for former rebels to target pre-electoral benefits to their wartime civilian constituencies-that is, areas populated by civilians predisposed to support former rebels due to shared grievances, self-interest, and security considerations (Kalyvas 2006). As in other electoral contexts, however, these predispositions must be (re)activated by former rebels during the election campaign (Holbrook and McClurg 2005). Given the strong intergroup cleavage after civil war, it is unlikely that rebels' wartime supporters would vote for the rebels' opponents in the short-term. But without being mobilized, former supporters are simply less likely to vote. There are three reasons for this.

First, even though civilian cooperation with rebels is widespread during war, wartime

\footnotetext{
${ }^{2}$ Some argue that targeting swing voters has the highest risk-to-benefit ratio, as targeting core supporters could be considered "lost investments" (Dixit and Londregan 1996). In contrast, others argue that targeting core voters is rational, particularly when the party needs to ensure voter turnout (Cox and McCubbins 1986; Nichter 2008).
} 
civilian support does not automatically translate into strong party-voter links after war. Civilian support during war results from a variety of motives, such as personal protection, economic advantages, or ideological conviction (Kalyvas 2006). These motives can disappear once the war has ended: Civilians might not require protection anymore, they might earn income outside of rebels' support economies, or might consider the ideological struggle either completed or not as important enough anymore. Former rebels therefore need to mobilize electoral support.

This situation for former rebels is similar to the one faced by party elites with weak ethnic party-voter links in Africa (Eifert, Miguel, and Posner 2010). In settings where ethnicity is salient, but only weakly so, co-ethnics are neither likely to vote unconditionally for their ethnic party nor will they vote for the opposition. Instead, these voters are more likely to abstain from turning out to vote at all if they are not mobilized. As a result, ethnic parties in contexts of weak party-voter links predominantly target benefits to electoral strongholds within the broader ethnic base (Nichter 2008; Rauschenbach and Paula 2019).

Second, rebels have a unique advantage over other parties in that they already have detailed information about where these wartime supporters are located: in areas that rebels controlled during the war. Frequently, rebel groups establish governance structures where they enjoy extensive civilian support (Arjona, Kasfir, and Mampilly 2015). During war, these areas are characterized by a stable rebel presence, little violence by rebels against civilians, and often, but not exclusively, a limited ability of government forces to access specific parts of the country (Kalyvas 2006). The close interaction between these rebel collaborators and the local population allows the rebel group to gather a wealth of information about the civilian population, for example, what services they need or what political demands they have. This information is still available to the rebels after the end of the war. It thus serves as a heuristic shortcut about potential voter preferences and voter locations.

Finally, rebels can reap loyalty benefits by allocating specifically material benefits to core supporters. Former rebels often distribute economic peace dividends among ex-combatants to secure the rank-and-file loyalty necessary to uphold the peace (Tajima 2016). It is similarly rational for former rebels to distribute material benefits to core voters to build long-term 
political support (Briggs 2012; Kramon 2017). If former rebels neglect wartime civilian supporters in a setting with recurrent elections, rebels might not simply risk voter abstention in the current election, but they actually risk voter defection to the opposition if past loyalty is not rewarded. This pressure is amplified by voters' demands for material retribution for their wartime struggle-demands that are particularly prevalent among those that were subject to indiscriminate wartime violence by the government: rebels' wartime civilian supporters.

Hypothesis 1: Leaders of former rebel groups running for office in post-conflict elections will steer pre-electoral benefits to areas of wartime popular support.

\section{Rebel Organization and Post-Conflict Brokers}

The organizational legacy of war equips post-conflict parties and candidates with the logistical capacity to efficiently engage in a targeted mobilization strategy. Specifically, rebels' wartime military organizations provide two things, the blueprint for a party structure and brokers within that party structure.

A functioning clientelist strategy requires party leaders who specify policies and who determine the distribution of resources for clientelist purposes. Moreover, such a strategy requires party officials who execute these tasks. Post-conflict parties which emerge from rebel organizations constitute the natural blueprint for such a structure (Manning 2008): Fighting a civil war and controlling territory requires the organizational coherence of an insurgent force. Without tightly knit networks of soldiers within combat units fighting the war on the ground, organized violent opposition against the state and establishing territorial control is nearly impossible (Weinstein 2007). The personal relationships built between soldiers and their commanders within their units and between commanders and their political leadership remain pervasive even after formal conflict termination and often even survive formal demobilization programs (Themnér 2015). These hierarchical structures form the basis for an organizational structure, typically in the form of a party, but possibly also in looser knit campaign teams, that can rely on established hierarchies to effectively execute political mobilization.

However, to be able to leverage this party structure to successfully execute an clientelist 
mobilization strategy, former rebel leaders and their officials also need local intermediaries. They provide further information about voter preferences and distribute resources (Stokes et al. 2013). These brokers are embedded in their local communities and have frequent face-to-face interactions with voters.

Again, rebels' wartime organization provides rebels running for office with the recruits that can function as brokers. While mid-level commanders might be able to join the political elite of a post-conflict party, these channels are often closed to rank-and-file soldiers. Instead, rebel soldiers still rely on their former commanders for a living. These soldiers are often the ones who return to their home villages from which they were recruited, either voluntarily or forcibly. Former soldiers' embeddedness in wartime military networks, their economic dependency structure, together with local knowledge provide former rebels with the basis of a broker network. Its unique combination of hierarchy, networks, loyalty, and local embeddedness make rebels' (former) military organizations therefore an effective channel through which rebels can implement a clientelistic mobilization strategy.

Hypothesis 2: Leaders of former rebel groups running for office in post-conflict elections will distribute resources predominantly through their former military networks.

\section{Access to Peace Dividends and Resource Allocation}

The third wartime legacy that facilitates a clientelistic mobilization strategy after civil wars is the degree to which rebels have access to economic peace dividends that they can repurpose for electoral benefits. A core assumption of the theoretical model presented so far is that rebels possess material resources to distribute in the first place. This resource access is typically determined by the design of a peace agreement-with important implications for how rebels target which types of pre-electoral benefits.

When rebels strike a peace deal with a government, they often gain access to political and economic resources in return (Haass and Ottmann 2017). These resources can come in the form of shared ownership of parastatals in resource-driven conflicts, as lucrative ministry positions in post-conflict governments, or in the form of enormous reconstruction or disarmament aid programs, which often directly target rebels (Haass and Ottmann 2021; 
Tajima 2016; Zürcher et al. 2013). These peace dividends equip rebels with resources that they can allocate for political reasons (Kramon and Posner 2013).

Rebels' ability to access and repurpose peace dividends for electoral goals depends on the discretionary control they have over these funds (Stokes et al. 2013). This discretionary control is a function of the number of actors involved in the decision-making process over resource allocation and the strength of the institutional rules that prevent misappropriation. Where many actors, potentially even with veto power over resource allocation decisions, meet strong external oversight over allocation decisions, rebels' ability to repurpose funds for electoral benefits is limited. Alternatively, when rebels do not have to coordinate with other actors over fund allocation and where oversight is weak, we should observe much more pronounced targeting of electoral benefits to rebels' wartime supporters.

Hypothesis 3: Electorally motivated resource allocation by former rebels running for office will be more pronounced when former rebels have more discretionary control over resources.

\section{Empirical Case: Post-Conflict Aceh}

We test these hypotheses in the context of the first post-conflict elections in the Indonesian province of Aceh in 2006. The GAM insurgency started in 1976 with the aim to establish an independent state of Aceh. This conflict waged on until the Boxing Day Tsunami of December 2004 laid waste to the province. Subsequent peace negotiations between GAM and the Indonesian government led to the Memorandum of Understanding (MoU) which ultimately ended the conflict in 2005 (International Crisis Group 2006b). Existing sources point to a number of characteristics of the MoU and the 2006 gubernatorial elections that make the Acehnese context a useful case to test our theory.

\section{Wartime Popular Support}

One of these characteristics is that wartime popular support for GAM rebels and government forces varied considerably across the province (Barter 2015; Clark and Palmer 2008; Tajima 2010). Rebel strongholds were predominantly found in the northeastern parts of the province, in districts ranging from Aceh Besar through Pidie, Bireuen, Lhokseumawe and 
Aceh Timur (Barter 2015, 346). There, the share of ethnic Acehnese was dominant, and thus also popular support for rebels (Aspinall 2009a, 196). Some of these areas were even governed by GAM delivering crucial social services. As a result of this high level of support for the insurgents, the Indonesian security forces often relied on indiscriminate violence to "punish" villages that allegedly housed GAM fighters (Sukma 2004).

In the provincial capital, Banda Aceh, and the west coast and central highlands, popular support for the GAM insurgency was less widespread. Banda Aceh as the administrative center of the province naturally was a state stronghold and popular support in the west coast was largely driven by military considerations with government forces enjoying support in the easily accessible flat lands and GAM rebels constrained to the hills (Barter 2015; Tajima 2010). Finally, the central highlands are areas with sizeable non-Acehnese populations, such as Gayo and/or Javanese. The distinct Acehnese identity of GAM led these non-Acehnese ethnic groups to support state forces which, in turn, were more restrained in their use of violence. As a consequence, GAM rebels relied more strongly on violence to enforce civilian support (Barter 2013; Breslawski 2021).

\section{The 2006 Elections}

Another useful characteristic of the Acehnese case is that the outcome of the first post-conflict election in 2006 was far from certain, making electoral mobilization necessary for all candidates running for office. A key provision of the $2005 \mathrm{MoU}$ was the promise of local elections (or pilkada) for provincial governor and the heads (bupati) of all 21 districts in Aceh. They were held between December 2006 and January 2006 and largely hailed as free and fair (International Crisis Group 2007).

In the run-up to these first post-conflict elections, the wartime allegiances and hostilities between civilians, GAM rebels, and government representatives appeared to be in flux. Political competition between Acehnese elites of all stripes was intense and a realignment of political allegiances and polity priorities took place (Clark and Palmer 2008). One of the most important developments was a split within GAM between its political leadership in 
exile and younger field commanders (Stange and Patock 2010). ${ }^{3}$ Against this background of internal strife, a GAM victory in the elections-even in their own heartlands-was widely discounted (International Crisis Group 2006a).

Once the results came in, however, GAM candidates won the governorship overwhelmingly and also comfortably won bupati elections in seven districts. It also became obvious that they won in their wartime strongholds and managed to extend their reach into areas that are not even ethnically Acehnese (International Crisis Group 2007).

\section{Post-Tsunami Aid}

A final useful feature of the Acehnese case is that it enables us to study post-conflict electoral mobilization in the context of a hard case: the allocation of post-tsunami aid. While the 2006 elections were deemed free and fair, observers also conceded that electoral mobilizationespecially in district races_-relied heavily on clientelistic practices:

[...] when visiting villages, candidates and tim sukses [campaign teams] would often make donations to the mosque fund or to social groups such as womens Quran study groups [...]. These donations demonstrated that the candidate cared and would take concrete action to improve the lives of villagers. One mukim (traditional leader of a cluster of villages) acknowledged that such 'donation campaigns' (kampanye amal) were the most effective way to acquire votes. (Clark and Palmer 2008, 29)

So far, research has not been able to trace the sources of the funds enabling these clientelistic practices or whether these practices also came in other form and shape, such as infrastructure projects. Circumstantial evidence points to the large amount of aid flowing into Aceh after the Boxing Day tsunami of 2004. Here, especially the approximately USD 8 billion in post-tsunami reconstruction aid were of importance, dwarving the approximately USD 360 million in post-conflict aid (Parks, Colletta, and Oppenheim 2013, 46).

\footnotetext{
${ }^{3}$ We explore the implications of the internal GAM split in more detail in Appendix D.3.
} 
To oversee aid distribution, the Indonesian government established the Agency for the Rehabilitation and Reconstruction of Aceh and Nias (Badan Rehabilitasi dan Rekonstruksi (BRR) NAD-Nias). GAM representatives had considerable influence in this agency with one former GAM spokesman, Teuku Kamaruzzaman, even becoming the head of its executive agency (Nicol 2013; Stange and Patock 2010). ${ }^{4}$ Subsequently, former GAM combatants and the rebels' wider organizational network appeared to benefit disproportionately from reconstruction projects funded through BRR (Aspinall 2009b).

Studying post-disaster aid allocation through the BRR presents a hard test for our theory. Even though there is evidence that the post-conflict reintegration funds served as patronage among former GAM combatants (Tajima 2016), there was strong international and national pressure in Aceh that the post-tsunami aid should be shielded from corruption (Nicol 2013). At the same time, in Sumatra-the island where Aceh is located-clientelism has historically been lower than in other Indonesian regions, such as Eastern Indonesia or Kalimantan (Aspinall and Berenschot 2019, 237). Finding electorally motivated aid allocation patterns despite these context conditions should improve our confidence in the results.

\section{Data and Research Design}

Estimating the effect of wartime legacies on electoral mobilization is a difficult task. Our theory requires fine-grained data on location, timing, and type of resource allocation, as well as spatial data on rebel wartime support. Aceh is one of the few cases where such data is available. We triangulate data from three different sources: georeferenced data on wartime violence events from the National Violence Monitoring System (Sistem Nasional Pemantauan Kekerasan, SNPK); a sub-district (kecamatan) level dataset on post-tsunami aid projects from the BRR's Recovery Aceh/Nias (RAN) database; and data from a survey of Acehnese village heads conducted in the context of a 2007 World Bank impact evaluation.

\footnotetext{
${ }^{4} \mathrm{~A}$ BRR organigram is presented in Appendix A.
} 


\section{Sub-District-Level Data}

Our main explanatory variable is a measure of GAM support in a given sub-district. Given scarce information during the Acehnese insurgency, it is difficult to measure territorial variation in GAM support directly. Building on Kalyvas' (2006) "control-collaboration" theory, we argue that areas of strong GAM support are characterized by (1) strategic violence between the government and rebels (2); high levels of indiscriminate violence by the government; and (3) low levels of rebel violence against civilians.

We use georeferenced information on the location of battle violence and violence against civilians from Indonesia's National Violence Monitoring System (SNPK) (Government of Indonesia 2018) to translate this theoretical idea into an empirical measure of wartime GAM support in Aceh. ${ }^{5}$ Since the SNPK started collecting data in 1998, we include events between 1998 and 2004, the year the violent conflict ended. We use the SNPK to measure the three types of violence conceptualized above on the sub-district levels: battles between the GAM and the Indonesian military (Tentara Nasional Indonesia, TNI), as well as violence against civilians by both the GAM and the TNI. We code an event as one-sided violence (OSV) by the TNI if one participating actor is originally coded as TNI or the police and the other actor is not GAM-and vice versa for OSV by GAM. Correspondingly, we code as battle violence (BV) all events that feature GAM and TNI/police as participants.

Using this information, we empirically capture the degree of GAM support as the following fraction:

$$
G A M \text { support }_{i}=\frac{T N I B V_{i}+\text { TNI OSV }}{\text { GAM OSV }}+1
$$

where TNI $B V_{i}$ is the number of conflict events between the TNI and GAM in sub-district $i$, TNI OSV $i$ is the number of one-sided violence events against civilians perpetrated by the Indonesian military in sub-district $i$, and $G A M O S V_{i}$ is the number of one-sided violence events by GAM in sub-district $i$ (plus a constant so the fraction becomes not infinite if GAM OSV is zero). The sum of battle events in the numerator reflects the idea that the government

\footnotetext{
${ }^{5}$ See Appendix C.2 for more details on the SNPK data.
} 
strategically targets rebel strongholds and had to resort to indiscriminate violence in areas where it did not have full control. The count of GAM OSV $V_{i}$ in the denominator scales the measure by the extent to which GAM targeted civilians in a district, which indicates little control.

This fraction has the useful property that if the numerator is large and the denominator is small the resulting value for GAM support ${ }_{i}$ becomes large. This scenario describes a district with high levels of battle violence and indiscriminate TNI violence against civilians, but little one-sided violence by the rebel group-which is precisely the pattern of violence we would see in areas with high GAM support (Breslawski 2021). Moreover, by including event counts both in the numerator and denominator we flexibly control for the overall occurrence of conflict events, which could stem, for instance, from population differences.

We link the cross-sectional measure of GAM support to original time-varying data on post-tsunami aid allocation from the BRR. Set up in the aftermath of the tsunami to coordinate the enormous inflow of aid, this database collected comprehensive information on timing, number, location, sector, and donor agencies of post-tsunami aid projects. We webscraped the (now defunct) online RAN database to obtain information on all 2,033 projects stored in the database. These aid projects were predominantly aimed at strengthening infrastructure or social cohesion, including sectors such as health, religion, administration, and infrastructure such as housing. Consequently, we think of these projects as non-rivalrous, excludable club goods whose benefits mostly accrue to the entire, or at least parts, of the targeted community, but not to other communities.

We extract precise information on project start dates, and aid volume in constant USD. We manually georeferenced the sub-district location names to Indonesian BPS sub-district codes, allowing us to match the data to the GAM support information in the sub-district level. From this information, we construct our dependent variables: the (log) count of new aid projects in a sub-district month, as well as the logged value of committed USD per project. ${ }^{6}$

\footnotetext{
${ }^{6}$ See Appendix C.1 for details on the RAN data collection.
} 


\section{Village-Level Survey Data}

We also analyze information from a survey of 756 individual village heads taken from the Aceh Livelihood and Reintegration survey (ARLS). The ARLS was conducted in the context of the evaluation of a World Bank community-driven development program, the BRA-KDP, between September and July 2008 (Barron et al. 2008). While its primary goal was to assess the effectiveness of BRA-KDP, the evaluation also contained a module that collected data from those villages where the individual-level surveys were conducted. It contains detailed information on if, and in which year, a village received tsunami assistance. As the survey is a cross-sectional snapshot of 2008, we cannot directly exploit variation in aid allocation before/after the 2006 election in the village data. Nevertheless, the survey provides the respondents' answer to when the village first received post-tsunami aid (Q138).

We use this information to generate two dependent dummy variables: reception of tsunami aid in 2005 and 2006. We set the variables to zero if tsunami aid was received after 2006, since this is unlikely to be a result of electoral mobilization. We expect that mostly aid in 2006 should be allocated as a function of electoral mobilization. In 2005, the immense destruction of the tsunami likely overshadowed political concerns. Moreover, the closer the electoral date, the higher the electoral pressure to generate support. We correlate this measure of tsunami aid with a dummy variable that captures a village head's positive response to the question "In your judgement, during [the 2001-2005] period, do you think the majority (at least half) of the members of the village supported GAM-TNA?"

\section{Descriptive Evidence}

Figure 1 provides three pieces of descriptive evidence that inform our subsequent analysis. ${ }^{7}$ First, GAM support varied markedly during the conflict (Panel A). Particularly areas in the North-east of the province are characterized by GAM support, whereas it was weaker in Central and South Aceh, consistent with the qualitative evidence from the conflict (Barter 2015). Second, tsunami aid was mainly allocated in the South-west coast of Aceh, where

\footnotetext{
${ }^{7}$ See Appendix B for summary statistics.
} 
Figure 1. GAM support and post-tsunami aid allocation in Aceh

A

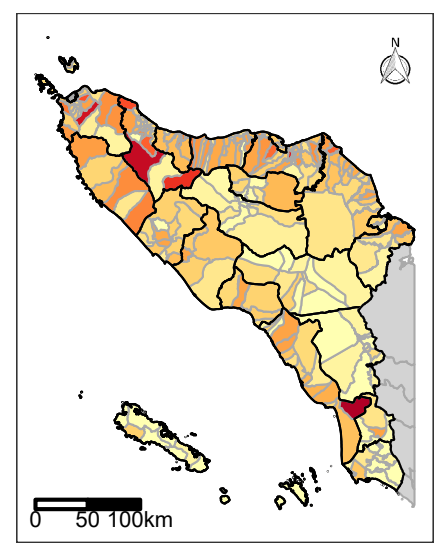

$\begin{array}{lllll}\text { GAM support } & & 1 & 1 & \\ 0 & 5 & 10 & 15 & 20\end{array}$
B

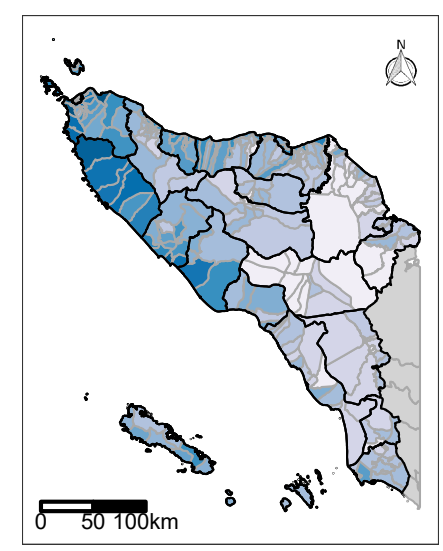

Number of projects $(\log +1) \begin{array}{llllll}0 & 1 & & & & \\ 0 & 1 & 3 & 4\end{array}$
C

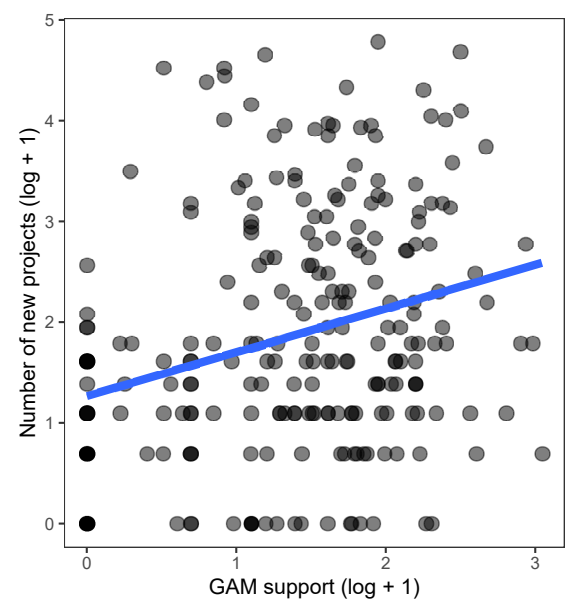

tsunami damage was highest (Panel B). At the same time, we observe that other regions in Aceh, too, benefitted from the aid influx, even though they may have not been hit as hard as the South-west. As the aid distribution pattern visible in the map follows the tsunami damage patterns, this provides at least some face validity for the geocoding accuracy in the BRR aid data. Finally, in line with our theory, the scatterplot in Panel C suggests a positive relationship between GAM support and aid allocation between 2005 and 2008 .

\section{Empirical Strategy}

We analyze the two datasets in two steps. First, we rely on a difference-in-differences (DiD) strategy to isolate a causal effect of wartime popular support on the distribution of preelectoral benefits. We compare the two years prior to the first post-conflict election (20052006) and two years after (2007-2008). This comparison exploits the fact that, if targeted benefit allocation were to occur, this should affect GAM sub-districts predominantly prior to the 2006 election, as political mobilization needs to take place before an election.

We estimate the difference-in-differences setup in a standard regression framework:

$$
\begin{aligned}
\text { Aid }_{i t}= & \beta_{1} \text { Pre-Election }_{t}+\beta_{2} \text { GAM Area } \\
& + \\
& \beta_{3} \text { GAM Area }_{i} \times \text { Pre-Election }_{t}+\mu_{i}+\gamma_{t}+\epsilon_{i t}
\end{aligned}
$$


where $A i d_{i t}$ is the logged number or USD value of aid projects in sub-district $i$ in month $t$. GAM Area $_{i}$ is a binary indicator that is coded one for sub-districts that exceed the median of the GAM support measure of Equation 1 and zero otherwise. ${ }^{8}$ Pre-Election $_{t}$ is a dummy that identifies months prior to the election in December 2006. $\mu_{i}$ are sub-district fixed effects and $\gamma_{t}$ are month fixed effects. Given their perfect collinearity with sub-district and month fixed effects, $\beta_{1}$ and $\beta_{2}$ are not identified.

The coefficient of the interaction, $\beta_{3}$, is the main coefficient of interest. $\beta_{3}$ captures the difference-in-differences, i.e. the differences in the average number of aid projects in GAM support areas vs. non-support areas both before and after the elections in 2006. We expect $\beta_{3}$ to be positive and statistically significant. To account for serial correlation in the error term, we cluster standard errors on the sub-district level.

The difference-in-differences design has one critical advantage in the post-conflict and post-tsunami setting of Aceh. It allows us to hold constant time-invariant variables that could plausibly affect aid allocation. The most important of such variables is the extent of tsunami damage and conflict-affectedness. Both variables do not vary over time within subdistricts, however, and are therefore captured by the sub-district fixed effects. This means we can ensure that the results are not driven by the possibility of regions with GAM Support overlapping with the regions most affected by the tsunami. Another benefit of the temporal component of this research design is that it allows us to separate out simple resource redistribution between rebels and their combatants from electorally motivated resource allocation.

While a powerful causal identification strategy, the difference-in-differences setup is based on donors' willingness to accurately report information to the RAN database. Not knowing the extent to which they did so might introduce unknown bias. We therefore also test our theoretical expectations with the independently collected village-survey data. We predict a village's reception of tsunami aid from its support for GAM during the conflict by estimating the following equation:

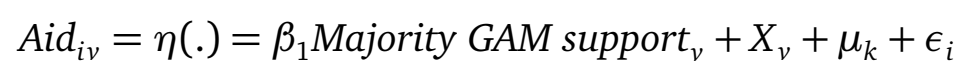

\footnotetext{
${ }^{8}$ We test other thresholds in robustness checks, see Appendix E.1.
} 
where $A i d_{i v}$ is a dummy for aid in a village $v$ in sub-district $i$. We estimate separate models for aid in 2005 (non-election year) and 2006 (election year). $\eta($.$) specifies the link function$ which we estimate both as $\eta()=.E(y)$, i.e. as a linear probability model, and as $\eta()=$. $\operatorname{logit}(\pi)$, a logit model. We cluster standard errors by sub-district to account for correlation within sub-districts. The linear probability specification allows us to compare effect sizes between the village data and the BRR data.

Importantly, the results from Equation 3 could be driven by confounding variables that determine both a village's level of GAM support and tsunami aid delivery. We therefore include a wide range of village-level covariates $X_{v}$ from the ARLS survey, including population size, poverty levels, conflict history, ethnic composition, internally displaced persons, as well as interviewer fixed effects and district (Kabupaten) fixed effects $\mu_{k}$ to account for unobserved variation across Aceh's regions. ${ }^{9}$ Most importantly, we also include a dummy variable indicating if a village was damaged by the tsunami. This allows us to isolate the effect of GAM Support from tsunami damage where those overlap. We present results with and without covariates to ensure that results are not biased by the post-treatment measurement of some of the covariates.

\section{Results}

\section{Where Do Electoral Benefits Go?}

Table 1 presents models that test the effect of wartime GAM support on the allocation of tsunami reconstruction projects before the 2006 gubernatorial elections (H1). Panel A displays model results based on the RAN database and SNPK information on GAM support areas. Models 1 and 3 represent the main DiD coefficent, using the number of projects (Model 1) and the volume of aid projects in USD (Model 3) on the sub-district level as dependent variables. Using two different indicators for aid allocation accounts for the possibility that electorally motivated aid targeting does not result in more projects, but rather in more valuable projects. Models 2 and 4 replicate the previous specifications aggregated on the district

\footnotetext{
${ }^{9}$ For a detailed list of the survey questions used to measure the covariates, see Appendix D.2.
} 
(kabupaten) level of analysis to control for unit aggregation bias.

Across all four models, the coefficient for GAM Area $\times$ Pre-Election is positive and statistically significant. The coefficient represents a sizable substantive effect: Based on the coefficient in Models 1 and 3 of Table 1, GAM areas received about 10.5\% more new aid projects or over $174 \%$ more in aid volume prior to the 2006 election than sub-districts without GAM support.

Panel B of Table 1 estimates the effect of wartime GAM support on the reception of tsunami aid using data from the village head surveys. The results corroborate the findings above. We do not observe a positive correlation between a dummy that captures whether the majority in a village supported GAM and the reception of tsunami aid in the non-election year 2005 (Models 1-4). This correlation changes once we employ reception of tsunami aid in 2006 as dependent variable. In the election year of 2006-when electoral concerns were more pressing than in 2005-we observe a positive and statistically significant relationship between GAM support and post-tsunami aid reception (Models 5-8). This result holds across estimators and does not change when we include a full set of controls.

The effect size of the coefficients reported in Models 5-8 is remarkably close to the effect size we obtain from the sub-district level data. In Model 5 in Panel A of Table 1, we estimate the DiD models with a binary outcome variable. The coefficient of this model is 0.08 whereas the coefficient of the comparable model from the ARLS data (Model 6) is 0.06. Thus, GAM areas were $6-8 \%$ more likely to receive tsunami aid prior to the elections. The similarity between both estimates is remarkably close given the different underlying datasets provides further supportive evidence for the robustness of the results. The validity of this effect size is further supported by anecdotal estimates from inside the BRR management that puts the degree to which BRR lost funds to corruption at about 5\% (Nicol 2013, 8)—a ballpark guess that is surprisingly close to our quantitative estimate.

\section{Who Distributes Electoral Benefits?}

We further propose that wartime military organizations provide an effective instrument for rebel elites to deliver electorally motivated goods (H2). Military organizations offer an 
Figure 2. Organizational Legacies and Electoral Benefits

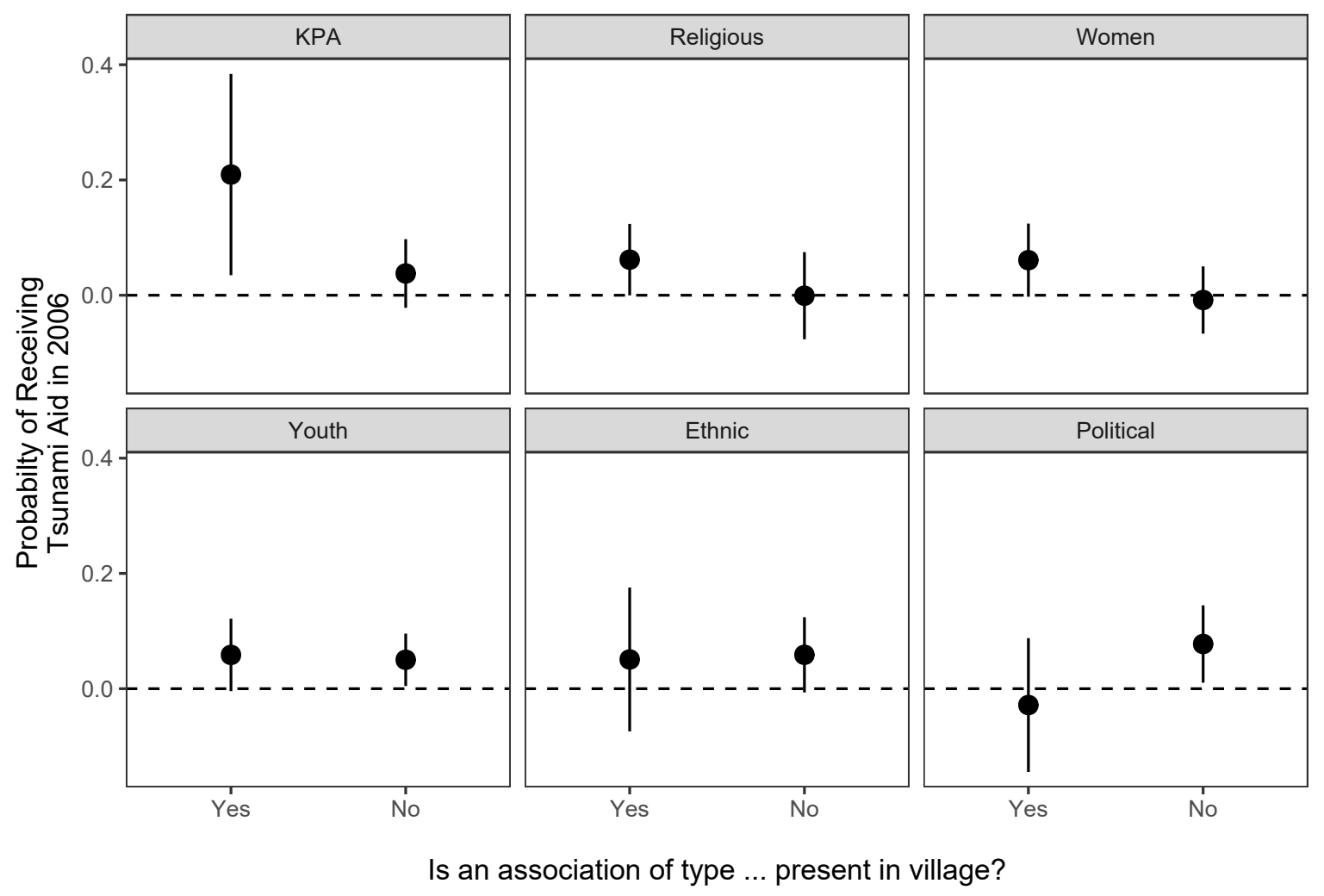

Note: Marginal effects from interacting the "Majority support for GAM" variable in Model 5 of Panel B in Table 1 with a dummy for the presence of the assocation indicated by the respective grid label. All models include the full set of covariates and district fixed effects. 95\% confidence intervals reported. 
Table 1. Targeted aid allocation to GAM strongholds prior to the 2006 elections in Aceh

Panel A: RAN Aid Database

\begin{tabular}{|c|c|c|c|c|c|}
\hline & \multicolumn{2}{|c|}{ No. of New Projects $(\log +1)$} & \multicolumn{2}{|c|}{ Aid Volume $(\log +1)$} & \multirow{2}{*}{$\frac{\operatorname{Pr}(\text { New Aid Project }>0)}{(5)}$} \\
\hline & (1) & (2) & (3) & (4) & \\
\hline GAM Area X Pre-Election & $\begin{array}{l}0.10^{* * *} \\
(0.03)\end{array}$ & $\begin{array}{l}0.48^{* *} \\
(0.23)\end{array}$ & $\begin{array}{l}1.00^{* * *} \\
(0.27)\end{array}$ & $\begin{array}{l}1.79^{* *} \\
(0.83)\end{array}$ & $\begin{array}{l}0.08^{* * *} \\
(0.02)\end{array}$ \\
\hline Geographical Unit & Sub-District & District & Sub-District & District & Sub-District \\
\hline Unit FE & Yes & Yes & Yes & Yes & Yes \\
\hline Month FE & Yes & Yes & Yes & Yes & Yes \\
\hline Observations & 9,640 & 840 & 9,640 & 840 & 9,640 \\
\hline Adjusted $\mathrm{R}^{2}$ & 0.41 & 0.69 & 0.34 & 0.56 & 0.34 \\
\hline
\end{tabular}

Panel B: ARLS Village Head Survey

\begin{tabular}{|c|c|c|c|c|c|c|c|c|}
\hline & \multicolumn{4}{|c|}{ Did village receive tsunami aid in $2005 ?$} & \multicolumn{4}{|c|}{ Did village receive tsunami aid in $2006 ?$} \\
\hline & \multicolumn{2}{|c|}{ OLS } & \multicolumn{2}{|c|}{ Logit } & \multicolumn{2}{|c|}{ OLS } & \multicolumn{2}{|c|}{ Logit } \\
\hline & (1) & (2) & (3) & (4) & (5) & (6) & (7) & (8) \\
\hline Majority in village supported GAM & $\begin{array}{c}-0.01 \\
(0.05)\end{array}$ & $\begin{array}{c}-0.04 \\
(0.05)\end{array}$ & $\begin{array}{c}-0.08 \\
(0.41)\end{array}$ & $\begin{array}{c}-0.28 \\
(0.45)\end{array}$ & $\begin{array}{c}0.06^{*} \\
(0.03)\end{array}$ & $\begin{array}{c}0.06^{* *} \\
(0.03)\end{array}$ & $\begin{array}{c}0.89^{* *} \\
(0.42)\end{array}$ & $\begin{array}{c}1.09^{* *} \\
(0.47)\end{array}$ \\
\hline Kab. FE & Yes & Yes & Yes & Yes & Yes & Yes & Yes & Yes \\
\hline Covariates & No & Yes & No & Yes & No & Yes & No & Yes \\
\hline Observations & 728 & 674 & 728 & 674 & 728 & 674 & 728 & 674 \\
\hline Adjusted $R^{2}$ & 0.20 & 0.25 & & & 0.04 & 0.04 & & \\
\hline Akaike Inf. Crit. & & & 783.22 & 714.65 & & & 359.26 & 347.93 \\
\hline
\end{tabular}

Note: ${ }^{*} \mathrm{p}<0.1 ;{ }^{* *} \mathrm{p}<0.05 ;{ }^{* * *} \mathrm{p}<0.01$

Panel A: OLS estimates reported, with robust standard errors clustered on geographical unit in parentheses. "Aid volume" refers to the committed project volume in constant USD. For multiple aid locations the volume is assumed to be evenly distributed across locations.

Panel B: Robust standard errors clustered by kecamatan in parentheses. Covariates: Tsunami affected, Village Population, Percent Ethnic Acehnese, IDPs, Poverty, Primary Schools, Conflict Victims, Interviewer Language, KPA present during interview. See Appendix C.3. 
established hierarchy and access to the networks of locally rooted combatants, enabling them to function as brokers who can mediate the distribution of goods on the local level.

After the peace agreement in 2005, GAM transformed its military wing into the veteran's organization Komite Perahlian Aceh (KPA) (or Aceh Transition Committee) (Barter 2015; International Crisis Group 2006a, 2007). The KPA established offices in all of Aceh's regions as well as in many villages and played a large role in mobilizing votes for GAM candidates, particularly in rural areas (International Crisis Group 2007, 3-4). Moreover, the KPA often moderated international agencies' access to some villages and negotiated protection of aid workers in remote areas (Nicol 2013). It is therefore plausible to assume that it was KPA presence that provided the channel through which GAM allocated electorally motivated tsunami aid to wartime supporters.

We expect the joint effect of KPA presence and wartime supporters on aid allocation to be more pronounced than the effect of other rebel-linked organizations in areas of wartime GAM support. During the insurgency and after, GAM formed alliances with organizations, such as the SIRA student association (Aspinall 2009b, 129ff.) or traditional Islamic scholars (ulama) (Barter 2011). These ties were much more limited, however, than the relationship between the GAM gubernatorial candidates and KPA. Moreover, these non-military organizations had much less internal coherence and capacity on which the GAM could draw to deliver benefits prior to the 2006 elections (International Crisis Group 2007).

We use the village survey data to model these expectations empirically. We interact the "Majority support for GAM" independent variable from our specification of Model 5 in Panel B of Table 1 with a dummy that indicates the presence of different organizations in a village. The grid labels in Figure 2 indicate the respective organization.

The results presented in Figure 2 are consistent with our expectations. KPA presence in villages where a majority supported GAM during the war raises the probability of receiving tsunami aid in 2006 by approximately 23\% (upper left panel). This is a substantively large effect, given our 6-8\% baseline estimate of wartime support presented in Table 1 . We find no comparable effect for other organizations. 
Figure 3. Oversight, Discretionary Control, and Benefit Allocation

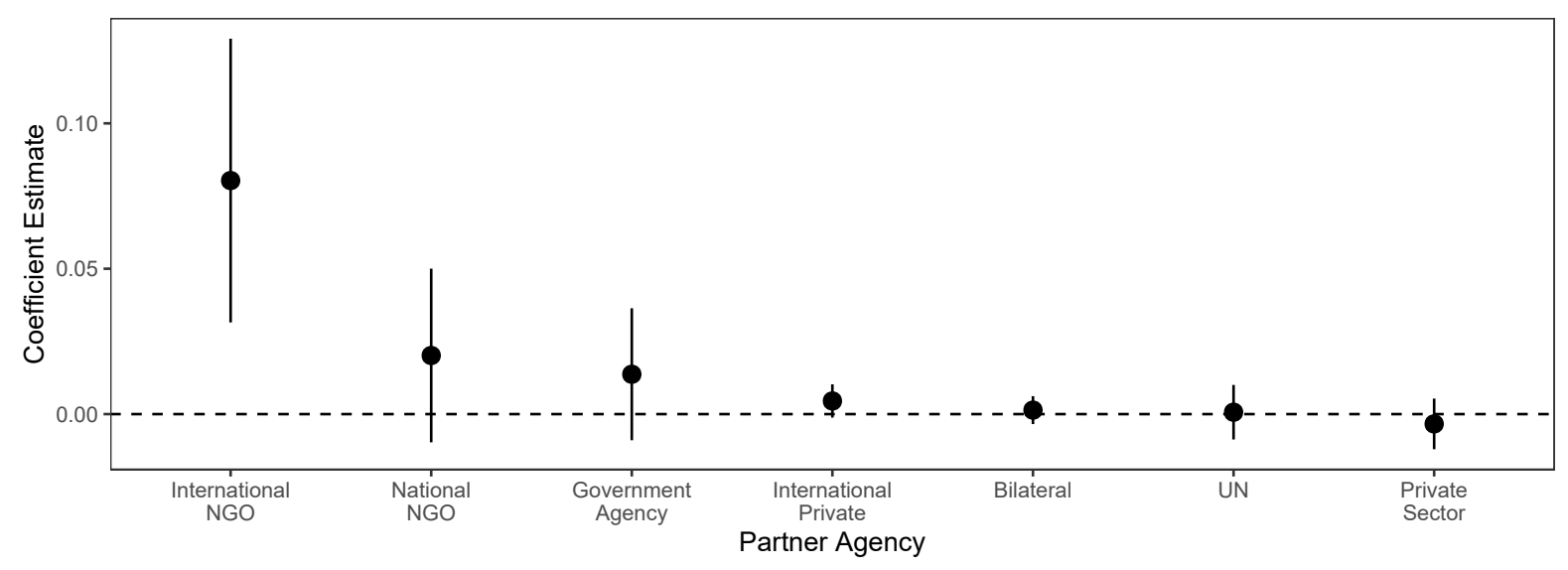

Note: Estimates of the GAM Area $\times$ Pre-Election 2006 coefficent from Model 1 in Panel A of Table 1, with 95\% confidence intervals. X-axis labels indicate the project counts in the respective partner category as dependent variable.

\section{How Are Electoral Benefits Distributed?}

We also test the proposition that former rebels' degree of discretionary control over resources shapes the effect of electorally motivated benefit allocation (H3). Where rebels' discretionary control over resources is high, we should see particularly pronounced effects of clientelistic targeting of resources to wartime support communities. To test this hypothesis, we exploit the fact that the BRR recorded an implementing partner for each aid project. This implementing partner variable denotes the agency from which the funding for a specific project originates, differentiating between national and international NGOs, the private sector, the UN, bilateral aid agencies, and Indonesian government agencies, including the BRR itself (Nicol 2013).

We expect oversight over project funding implementation to be lower-and thus rebels' possibilities to influence allocation to be larger-for national and particularly international non-governmental organizations. NGOs typically lack the capacity to strictly enforce anticorruption rules. In negotiating choice of and access to project locations these organizations need to rely very strongly on local cooperation partners (Nicol 2013, 121), which makes them more susceptible to influence by GAM interests. Most international aid agencies, on the other hand, specifically by large bilateral donors, such as USAID, GIZ, or DFID, have strong 
anti-corruption norms and procedures in place (Overseas Development Institute 2005, 22). It is more difficult for former rebels to circumvent these procedures. Due to less discretionary control, we expect the joint effect of wartime support and pre-2006 election period to be less pronounced for bilateral and national government implementing partners.

Figure 3 plots the GAM Area $\times$ Pre-Election coefficient from Model 1 in Panel A of Table 1, using the number of aid projects with different implementing partners as dependent variable. The DiD coefficient is particularly large and statistically significant when we employ projects with international NGOs as dependent variable. It is also somewhat larger, but statistically imprecise when we look at national NGOs and Indonesian government agencies. For bilateral, international private partners, the UN, and the Indonesian private sector, the coefficient becomes close to zero with narrow confidence intervals overlapping zero, suggesting, as expected, a null effect for these types of project partners. This finding suggests that the degree in discretionary control shapes how former rebels target electorally motivated benefits.

\section{Additional Implications, Alternative Explanations, and Robustness Tests}

In the Appendix, we explore a number of alternative explanations and robustness tests. In Appendices D.1 and D.2, we implement two alternative tests of hypothesis 2 and 3 using additional data from the BRR aid data and the ARLS survey. The results support our hypotheses, further improving the plausibility of our findings.

Another concern might be that the internal split within GAM prior to the 2006 elections affects the results. In Appendix D.3, we therefore combine qualitative case evidence with an analysis of district-level voting results across the two GAM factions to show that this concern is unjustified. If anything, the additional results are in line with our theoretical expectations: The faction that commanded the strongest control over GAM's former military networks—and thus the potential to use those networks as brokers (see H2)—also performed the strongest in the 2006 elections, further strengthening confidence in the theory's applicability.

It is also worth considering if and how the BRR also gave government elites the oppor- 
tunity to target potential supporters with electoral benefits-and whether such access could offer an alternative explanation for our findings. However, a number of reasons suggest that the Indonesian government did not have strong incentives to use the BRR funds in an electorally strategic manner (Clark and Palmer 2008). First, the head the BRR was a delegate appointed by the government in Jakarta, not from the regional province. Consequently, he had fewer incentives to use BRR funds for electorally strategic purposes, since he himself did not stand for (re)election (Nicol 2013). Second, the acting incumbent governor of Aceh in 2006 did not run for re-election, thus limiting the incentive of the actual incumbent to influence BRR fund allocation. Finally, the Indonesian military fought the conflict extremely asymmetrically and violently, limiting the extent to which it was able to establish popular wartime support that could have been tapped for electoral mobilization (Sukma 2004).

We also account for a number of other alternative explanations. We demonstrate that the main DiD results are not driven by our cutoff choice for the GAM Support variable (Appendix E.1). We show that our results are not dependent on the measure we use to operationalize GAM support in the analysis of the village data (Appendix E.2). Moreover, we demonstrate the face validity of the SNPK GAM support measure, using data from the ARLS village data (Appendix E.3). We also reestimate the main models using UCDP data, obtaining largely similar results (Appendix E.4). Moreover, we offer results that show that our DiD results are not contingent on unit-specific trends (Appendix E.5) or spatial autocorrelation (Appendix E.6). We also test whether survey results are driven by heavy tsunami affectedness. We therefore exclude those villages from the survey that were located in districts that were particularly hard-hit by the tsunami (Appendix E.7). Results remain substantively similar. Finally, we demonstrate that the survey data do not show any correlation between GAM support and tsunami aid reception after the election in 2007, as our theory would predict (Appendix E.8).

\section{External Validity}

Our analysis of how wartime legacies drive rebels' electoral mobilization after civil war offers a number of generalizable insights beyond the Acehnese context. To establish the boundaries 
of this larger universe of cases, we discuss the relevant organizational legacies of rebellion against the backdrop of two key dimensions of (post-)conflict settings: the distribution of popular support during war and the nature of political order after war.

One dimension along which the external validity of our theoretical argument varies is the extent to which rebels enjoy wartime popular support. Our theory most strongly applies to cases where rebels resemble "stationary bandits": groups that provide governance functions in territories they fully or at least partially control, through provision of services, protection, and dispute resolution (Beardsley, Gleditsch, and Lo 2015; Reeder 2018; Stewart 2018). Examples of wars with such governance elements include the rebel-held territories in Northern Côte d'Ivoire or the SPLA administration in Southern Sudan. These governance strategies allow rebels to gather crucial information about the needs and demands of the local population (Kalyvas 2006). After war, rebels can use this information to target pre-electoral benefits to those areas who are most likely to support them to maximize mobilization.

In contrast, our theory is less applicable in contexts where rebels predominantly employ "roving bandit"-like strategies of killing civilians during war to coerce cooperation (Stewart and Liou 2017). Examples include the territory controlled by the group Liberians United for Reconciliation and Democracy (LURD) and Eastern Democratic Republic of Congo where Hutus were perpetrators as well as targets of civilian victimization. It is unlikely that voters who were targeted with violence during war will vote for those groups who perpetrated this violence even if these group allocate benefits for electoral mobilization.

Another factor that shapes the external validity of our argument is the type of conflict termination. The type of conflict termination influences the other two key legacies relevant to our theory of post-conflict clientelism: rebels' military networks and access to and control over peace dividends (Kreutz 2010; Ottmann and Vüllers 2019). When wars end through a military defeat of the rebel side, rebels' military structures are likely to be severely diminished or even dismantled. Even when former rebel elites are subsequently allowed to compete in elections, they will be unable to effectively transform the remnants of their military organization into party structures and broker networks (Joshi 2010). Moreover, given the weak position of defeated rebels against the winning side, rebels will typically not have 
access to post-conflict rents from government or in form of international aid. In these contexts, such as in the aftermath of the 2009 defeat of the Liberation Tigers of Tamil Eelam (LTTE) in Sri Lanka, we would expect our theory to hold less explanatory power.

Our theory is more applicable to civil wars that are resolved through negotiated settlements and-even more so-when these settlements contain extensive power-sharing arrangements. In these instances, rebels' bargaining power at the negotiation table often allows military networks to survive even extensive demobilization (Themnér 2017). Moreover, power-sharing arrangements that divide government ministries among belligerents-and thus access to spoils from government and international aid—enable former rebels to access and control at least parts of peace dividends for electoral purposes (Haass and Ottmann 2021; Ottmann 2020). These types of arrangements also typically stipulate elections as a key element of the post-conflict peace process. Electoral competition together with the three wartime legacies we identify makes clientelism an effective mobilization strategy. ${ }^{10}$

\section{Conclusion}

We study three legacies that shape how rebels engage in clientelistic electoral mobilization after civil wars. First, former rebels target wartime supporters with economic benefits prior to elections to mobilize voters. Second, rebels' wartime militaries provide them with broker networks for effectively allocating these benefits. Third, the ways in which rebels gain discretionary control over economic peace dividends shapes the way in which they are able to access and divert resources for electoral purposes.

To test these expectations, we analyze tsunami aid allocation in post-conflict Aceh prior to the province's first post-conflict gubernatorial elections in 2006. The Acehnese case offers us a unique glimpse into the usually hidden resource allocation process. Combining findings from original data on over 2,000 tsunami aid projects and World Bank data from a village

\footnotetext{
${ }^{10}$ Note that our theory should apply both to regional elections in the aftermath of an autonomy conflict as well as to national elections after a conflict about control of the government. These elections may differ in scope of the control they offer to the rebel group—regional or country-wide—but they do not limit the applicability of the three theoretical mechanisms sketched.
} 
survey we document that subdistricts with high wartime support for the GAM rebels received approximately $10 \%$ more tsunami aid projects than sub-districts without GAM support prior to the 2006 elections. We also show that rebels used their former military networks to distribute these resources. Moreover, electoral benefit allocation was particularly pronounced in aid sectors where external oversight over rebels' access to aid was low.

One key implication of this research concerns democratic quality in the aftermath of civil wars. Democracy after civil war is generally understood to be limited in nature (Wantchekon 2004). While many studies document that a minimum of electoral competition often does take place once a conflict has ended, the democracies that emerge out of war often display deficiencies in human rights, division of power, and electoral conduct (Zürcher et al. 2013). We add to this research the insight that wartime legacies can limit the quality of democracy through their effects on electoral clientelism. Future research should investigate the precise beneficiaries of post-conflict clientelistic mobilization. Does peace trickle down to individuals (even if mostly to former wartime supporters) or do peace dividends get lost on the way, for instance, mostly to broker networks or former rebel elites? Answering this question could yield important insights on how citizens' expectations vs. actual changes to their livelihood impact the quality of democracy after civil war.

A final implication of our research relates to the role of foreign aid in post-conflict contexts. Echoing research on the electoral repurposing of international aid (Briggs 2012; Jablonski 2014), our findings highlight a dilemma for external actors aiming to support war-to-democracy transitions. Enabling (even unvoluntarily) former rebels to access and repurpose peace dividends, such as aid, might stabilize the situation and reduce violence. But this access could undermine the quality of democracy in the long term, ultimately eroding the institutions that regulate political conflict through votes instead of violence. Future research needs to study which types of oversight arrangements are best suited to mitigate elite capture of peace dividends after civil wars. 


\section{Acknowledgements}

We thank Saiful Akmal, Susanna Campbell, Stefano Costalli, Lesley-Ann Daniels, Niheer Dasandi, Charlotte Fiedler, David Hudson, Lennart Kaplan, Jana Krause, Magnus Lundgren, Saiful Mahdi, Aila Matanock, Karina Mross, Jan Pierskalla, Andrea Ruggeri, Adam Scharpf, Gyda Sindre, Yuhki Tajima, participants at the University of Gothenburgs lunch seminar, AFK Methods Workshop 2019, IDD Research Seminar, Politics after War workshop 2020, and ISA 2019, EPSA 2019, and APSA 2019 conferences for helpful comments and discussions. We are grateful to Maria Ulfah for excellent research assistance.

\section{References}

Arjona, Ana, Nelson Kasfir, and Zachariah Mampilly, eds. 2015. Rebel Governance in Civil War. Cambridge: Cambridge University Press.

Aspinall, Edward. 2009a. "Combatants to Contractors: The Political Economy of Peace in Aceh." Indonesia , 1-34.

Aspinall, Edward. 2009b. Islam and Nation: Separatist Rebellion in Aceh, Indonesia. Stanford, CA: Stanford University Press.

Aspinall, Edward, and Ward Berenschot. 2019. Democracy for Sale: Elections, Clientelism, and the State in Indonesia. Ithaca, NY: Cornell University Press.

Barron, Patrick, Laura Paler, Macartan Humphreys, Yuhki Tajima, and Jeremy Weinstein. 2008. Research Design for the Aceh Reintegration and Livelihood Surveys. Washington, D.C./Jakarta: The World Bank.

Barter, Shane Joshua. 2011. "Ulama, the State, \& War: Community Islamic Leaders in the Aceh Conflict." Contemporary Islam 5(1): 19-36.

Barter, Shane Joshua. 2013. "State Proxy or Security Dilemma? Understanding Anti-Rebel Militias in Civil War." Asian Security 9(2): 75-92. 
Barter, Shane Joshua. 2015. "Zones of Control \& Civilian Strategy in the Aceh Conflict." Civil Wars 17(3): 340-356.

Beardsley, Kyle, Kristian Skrede Gleditsch, and Nigel Lo. 2015. "Roving Bandits? The Geographical Evolution of African Armed Conflicts." International Studies Quarterly 59(3): 503-516.

Birch, Sarah, Ursula Daxecker, and Kristine Höglund. 2020. "Electoral Violence: An Introduction." Journal of Peace Research 57(1): 3-14.

Breslawski, Jori. 2021. "The Social Terrain of Rebel Held Territory." Journal of Conflict Resolution 65(2-3): 453-479.

Briggs, Ryan C. 2012. "Electrifying the Base? Aid and Incumbent Advantage in Ghana." The Journal of Modern African Studies 50(04): 603-624.

Clark, Samuel, and Blair Palmer. 2008. Peaceful Pilkada, Dubious Democracy : Aceh's PostConflict Elections and Their Implications. Technical report The World Bank.

Costalli, Stefano, and Andrea Ruggeri. 2019. “The Long-Term Electoral Legacies of Civil War in Young Democracies: Italy, 1946-1968." Comparative Political Studies 52(6): 927-961.

Cox, Gary W., and Mathew D. McCubbins. 1986. "Electoral Politics as a Redistributive Game." The Journal of Politics 48(2): 370-389.

Daly, Sarah Zukerman. 2019. "Voting for Victors: Why Violent Actors Win Postwar Elections." World Politics 71(4): 747-805.

Daxecker, Ursula, Elio Amicarelli, and Alexander Jung. 2019. “Electoral Contention and Violence (ECAV): A New Dataset.” Journal of Peace Research 56(5): 714-723.

De Juan, Alexander, and Jan Henryk Pierskalla. 2016. "Civil War Violence and Political Trust: Microlevel Evidence from Nepal." Conflict Management and Peace Science 33(1): 67-88.

Dixit, Avinash, and John Londregan. 1996. "The Determinants of Success of Special Interests in Redistributive Politics." Journal of Politics 58(4): 1132-1155. 
Eifert, Benn, Edward Miguel, and Daniel N. Posner. 2010. "Political Competition and Ethnic Identification in Africa." American Journal of Political Science 54(2): 494-510.

Flores, Thomas Edward, and Irfan Nooruddin. 2012. "The Effect of Elections on Postconflict Peace and Reconstruction." The Journal of Politics 74(2): 558-570.

Fukuyama, Francis. 2014. Political Order and Political Decay: From the Industrial Revolution to the Globalization of Democracy. New York, NY: Farrar, Straus and Giroux.

Gates, Scott, Håvard Hegre, Håvard Mokleiv Nygård, and Håvard Strand. 2012. "Development Consequences of Armed Conflict." World Development 40(9): 1713-1722.

Golden, Miriam, and Brian Min. 2013. "Distributive Politics Around the World." Annual Review of Political Science 16(1): 73-99.

Government of Indonesia. 2018. "Sistem Nasional Pemantauan Kekerasan (National Violence Monitoring System)." https ://microdata.worldbank .org/index.php/catalog/ 2626.

Haass, Felix. 2021. "The Democracy Dilemma. Aid, Power-Sharing Governments, and PostConflict Democratization." Conflict Management and Peace Science 38(2): 200-223.

Haass, Felix, and Martin Ottmann. 2017. "Profits from Peace. The Political Economy of Power-Sharing and Corruption." World Development 99: 60-74.

Haass, Felix, and Martin Ottmann. 2021. "Rebels, Revenue and Redistribution: The Political Geography of Post-Conflict Power-Sharing in Africa." British Journal of Political Science 51(3): 981-1001.

Hadzic, Dino, David Carlson, and Margit Tavits. 2020. "How Exposure to Violence Affects Ethnic Voting." British Journal of Political Science 50(1): 345-362.

Hicken, Allen. 2011. "Clientelism.” Annual Review of Political Science 14(1): 289-310.

Holbrook, Thomas M., and Scott D. McClurg. 2005. "The Mobilization of Core Supporters: Campaigns, Turnout, and Electoral Composition in United States Presidential Elections." American Journal of Political Science 49(4): 689-703. 
International Crisis Group. 2006a. Aceh: Now for the Hard Part. Brussels/Jakarta: International Crisis Group.

International Crisis Group. 2006b. Aceh's Local Elections: The Role of the Free Aceh Movement (GAM). Brussels/Jakarta: International Crisis Group.

International Crisis Group. 2007. Indonesia: How GAM Won in Aceh. Brussels/Jakarta: International Crisis Group.

Jablonski, Ryan S. 2014. "How Aid Targets Votes: The Impact of Electoral Incentives on Foreign Aid Distribution." World Politics 66(2): 293-330.

Jarstad, Anna K., and Timothy D. Sisk. 2008. "Introduction." In From War to Democracy. Dilemmas of Peacebuilding, eds. Anna K. Jarstad, and Timothy D. Sisk. Cambridge: Cambridge University Press , 1-13.

Joshi, Madhav. 2010. "Post-Civil War Democratization: Promotion of Democracy in PostCivil War States, 1946-2005." Democratization 17(5): 826-855.

Kalyvas, Stathis N. 2006. The Logic of Violence in Civil War. Cambridge: Cambridge University Press.

Kalyvas, Stathis N. 2008. "Ethnic Defection in Civil War." Comparative Political Studies 41(8): 1043-1068.

Kitschelt, Herbert, and Steven I. Wilkinson. 2007. "Citizen-Politician Linkages: An Introduction." In Patrons, Clients and Policies: Patterns of Democratic Accountability and Political Competition. Cambridge: Cambridge University Press , 1-49.

Kramon, Eric. 2017. Money for Votes: The Causes and Consequences of Electoral Clientelism in Africa. Cambridge: Cambridge University Press.

Kramon, Eric, and Daniel N. Posner. 2013. "Who Benefits from Distributive Politics? How the Outcome One Studies Affects the Answer One Gets." Perspectives on Politics 11(2): 461474. 
Kreutz, Joakim. 2010. "How and When Armed Conflicts End: Introducing the UCDP Conflict Termination Dataset." Journal of Peace Research 47(2): 243-250.

Lake, Milli. 2017. "Building the Rule of War: Postconflict Institutions and the MicroDynamics of Conflict in Eastern DR Congo." International Organization 71(02): 281-315.

Manning, C. 2008. The Making of Democrats: Elections and Party Development in Postwar Bosnia, El Salvador, and Mozambique. New York, NY: Palgrave Macmillan.

Manning, Carrie, and Ian Smith. 2019. "Electoral Performance by Post-Rebel Parties." Government and Opposition 54(3): 415-453.

Matanock, Aila M. 2017. Electing Peace: From Civil Conflict to Political Participation. Cambridge: Cambridge University Press.

Nichter, Simeon. 2008. "Vote Buying or Turnout Buying? Machine Politics and the Secret Ballot." American Political Science Review 102(01): 19-31.

Nicol, Bill. 2013. Tsunami Chronicles: Adventures in Disaster Management. Amazon Digital Services.

Ottmann, Martin. 2020. "Peace for Our Time? Examining the Effect of Power-Sharing on Postwar Rebellions." Journal of Peace Research 57(5): 617-631.

Ottmann, Martin, and Johannes Vüllers. 2019. "Government-Rebel Relations in the Wake of Power-Sharing Peace Agreements." In Power Sharing and Power Relations After Civil War, eds. Caroline A. Hartzell, and Andreas Mehler. Boulder, CO: Lynne Rienner Publishers , 19-45.

Overseas Development Institute. 2005. Managing the Risks of Corruption in Humanitarian Relief Operations. Humanitarian Policy Group / Overseas Development Institute.

Parks, Thomas, Nat Colletta, and Ben Oppenheim. 2013. The Contested Corners of Asia: Subnational Conflict and International Development Assistance. San Francisco, CA: The Asia Foundation. 
Rauschenbach, Mascha, and Katrin Paula. 2019. "Intimidating Voters with Violence and Mobilizing Them with Clientelism." Journal of Peace Research 56(5): 682-696.

Reeder, Bryce W. 2018. "The Political Geography of Rebellion: Using Event Data to Identify Insurgent Territory, Preferences, and Relocation Patterns." International Studies Quarterly 62(3): 696-707.

Sindre, Gyda M. 2019. "Adapting to Peacetime Politics? Rebranding and Ideological Change in Former Rebel Parties." Government and Opposition 54(3): 485-512.

Sprenkels, Ralph. 2019. “Ambivalent Moderation: The FMLN's Ideological Accommodation to Post-War Politics in El Salvador." Government and Opposition 54(3): 536-558.

Stange, Gunnar, and Roman Patock. 2010. "From Rebels to Rulers and Legislators: The Political Transformation of the Free Aceh Movement (GAM) in Indonesia." Journal of Current Southeast Asian Affairs 29(1): 95-120.

Stewart, Megan A. 2018. "Civil War as State-Making: Strategic Governance in Civil War." International Organization 72(1): 205-226.

Stewart, Megan A., and Yu-Ming Liou. 2017. "Do Good Borders Make Good Rebels? Territorial Control and Civilian Casualties." The Journal of Politics 79(1): 284-301.

Stokes, Susan C. 2011. "Political Clientelism." In The Oxford Handbook of Political Science, ed. Robert E Goodin. Oxford: Oxford University Press.

Stokes, Susan Carol, Thad Dunning, Marcelo Nazareno, and Valeria Brusco. 2013. Brokers, Voters, and Clientelism: The Puzzle of Distributive Politics. Cambridge: Cambridge University Press.

Sukma, Rizal. 2004. Security Operations in Aceh: Goals, Consequences, and Lessons. Washington D.C.: East-West Center.

Tajima, Yuhki. 2010. Understanding the Livelihoods of Former Insurgents: Aceh, Indonesia. Technical Report 17 World Bank Washington, D.C./Jakarta: . 
Tajima, Yuhki. 2016. "Ex-Combatant Networks and Peacetime Benefits: Explaining Patronage in Postwar Aceh, Indonesia." Paper presented at the Annual Conference of the American Political Science Association, San Francisco.

Themnér, Anders. 2015. "Former Military Networks and the Micro-Politics of Violence and Statebuilding in Liberia." Comparative Politics 47(3): 334-353.

Themnér, Anders. 2017. Warlord Democrats in Africa: Ex-Military Leaders and Electoral Politics. London: Zed Books Ltd.

Wantchekon, Leonard. 2004. "The Paradox of "Warlord" Democracy: A Theoretical Investigation." American Political Science Review 98(1): 17-33.

Weinstein, Jeremy M. 2007. Inside Rebellion: The Politics of Insurgent Violence. Cambridge: Cambridge University Press.

Zürcher, Christoph, Carrie Manning, Kristie Evenson, Rachel Hayman, Sarah Riese, and Nora Roehner. 2013. Costly Democracy: Peacebuilding and Democratization After War. Stanford, CA: Stanford University Press.

\section{Biograhpical statements}

Felix Haass (felix.haass@stv.uio.no) is postdoctoral researcher at the University of Oslo, P.O. Box 1097, Blindern, 0317 Oslo. Martin Ottmann (m.ottmann@bham.ac.uk) is an Associate Professor in Peace and Conflict Studies at the University of Birmingham, Birmingham B15 2TT, United Kingdom. 